\title{
Governance in Crisis: Institutionalizing Reflective Report to Guide Decision Making Under Uncertainty
}

\author{
Abstract \\ This paper proposes a communication method to improve decision and policymaking \\ under uncertain scenarios. The motivation for elaborating such a method is the absence \\ of clarity, prioritization criteria and critical thinking in considerations made by the \\ Brazilian federal government during the ongoing response to the epidemic of COVID-19 \\ in the country. The expectation is that the implementation of this method would help \\ national leaders more easily assess the significance of evidence-based practices and \\ anecdata to the decisions they are urged to make under significant time and resource \\ constraints.
}

Keywords: crisis communication; cognitive psychology; decision making; uncertainty; covid-19; Brazil

\section{Introduction}

Neither science nor politics alone will make Brazil win its war against COVID-19. The current Minister of Health, who allegedly (Benites, 2020) argues in favor of science, failed to prevent rapid and high rates of community transmission of the novel coronavirus across the country. The elected president cannot think beyond political survival (Reuters, 2020). The minister needs to acknowledge fundamental containment and mitigation limitations the country faces in this pandemic. The president must admit that many challenges imposed by this virus will not be addressed by intuition or replicating foreign policies. The current national debate between evidence-based policy and anecdata will only prolong the exit to this unprecedented crisis (Ansell \& Geyer, 2017; Pinheiro-Machado, 2020). On the one had, the recency of and uncertainty around this pathogen makes tackling it uniquely from a traditional scientific standpoint less 
effective (Aguilera, 2020; Lunn et al., 2020). On the other hand, the chances of prescribing a course of action that has not been sufficiently scrutinized could pose great health risks to those seeking treatment and quickly backfire (Jiang, 2020; Godin, 2020). In this context, this article argues that erratic institutions can incrementally (Feitsma, 2018 , p. 9) improve governance during crises (Zeitlin, 2015, p. 9) by institutionalizing a straightforward reflective report format (Sen, 2010), verbal or written, among policy advisors. The expectation is that the incorporation of a methodology that favors critical thinking will help decision makers draw a more accurate picture (Pinto et al., 2018) of concerted actions (Cabannes \& Lipietz 2018) to address wicked problems (Head, 2008).

\section{Background}

Brazil's health minister waited until first reported cases in the country to come up with a plan to contain the spread of the new coronavirus (Lima, 2020). He also initially downplayed the effects of this epidemic. He said the Brazilians should wait and see how this virus would behave in warmer places (Folha de São Paulo, 2020). Such a statement was made despite regions in the same latitude having already expressed growing concern about the chances of community transmission (Khalik, 2020). The slow response of the minister to contain this virus has significantly affected the capacity of the country to come up with containment strategies such as testing, tracking and isolating infected and suspected cases (Reeves, 2020). 
In addition, the minister has apparently transferred the responsibility of his decisions to guidelines provided by the World Health Organization (WHO) (Falcão \& Vivas, 2020). This international body plays a key role in gathering and informing the international community about emerging health risks. However, it has been criticized for i) being slow in pandemic responses (Feldwisch-Drentrup, 2020), ii) deliberately ignoring key stakeholders (Mulier, 2020) and iii) proposing a policy ('test, test, test') (Wood, 2020) that is not feasible for ill-prepared countries. Brazilian public health authorities failed to prepare the country to carry out rapid, reliable and mass testing (Barifouse, 2020). Thus they cannot quickly identify cases and as a result track and link them to clusters. To make matters worse, the 'Wuhan approach' to enforce extensive and long lockdowns to suppress the spread of the virus is not feasible in large urban areas in Brazil due to the number of people living under the poverty line (Costa, 2020). If Wuhan-style lockdowns are to be enforced, the result would be chaos, like India has been witnessing (Bisht, 2020). Also, the poor in Brazil, under the current welfare system, have already made it clear that they would rather die of respiratory-related illnesses than of hunger (Vespa, 2020). Therefore, the strategy to reduce the risk of mortality among the most vulnerable in Brazil needs to be adapted to the country's socioeconomic conditions (Dunn et al., 2020; Ghebreyesus, 2020). At the current rate of uncontrolled community transmission, this solution depends on a treatment or a still-distant vaccine (Fauci, 2020) to ensure Brazilians can safely return to 'normal life' while protecting the most vulnerable within their inner social circles. Until then, the national leader and his close advisors need to 
avoid that this health crisis turns into a devastating social and economic crisis (Albertus, 2020).

The Brazilian president has advocated that doctors prescribe a contested medication to fight the disease (COVID-19) caused by the new coronavirus (SARS-CoV-2) (Jornal Nacional, 2020). This claim follows the echoes of the U.S. president (ABC News, 2020). However, the scientific community is cautious about prescribing such medicine due to lack of randomized controlled trials that verify the safety and effectiveness of such medicine to combat this respiratory disease (Piller, 2020). In Brazil, there has been anecdotal evidence that such medical treatment should be administered (Folha de São Paulo, 2020a). The Minister of Health and research institutes in the country, however, have been cautious about recommending this treatment to the public at large (Globo, 2020; Governo do Brasil, 2020). The minister, instead, has sided with the World Health Organization's mitigation policy of stay-at-home and social distancing as preferred methods to break infection chains (Resende \& Matoso, 2020). The expectation is that such policies will momentarily bring infection rates down and thus reduce the chances of public health services collapsing due to the surge number of patients seeking hospitalization concomitantly (Jansen, 2020).

The president, however, argues that stay-at-home orders, as enacted by state governors, should be immediately halted (Jornal Nacional, 2020a). He argues that losses in the economy are to cause more suffering to the country than the expected 
death of thousands of vulnerable individuals (UOL, 2020). The Brazilian society is as of now divided into following the president economic perspectives or complying with scientific reassurances (Estadão, 2020).

\section{Theoretical Framework}

The clash observed in Brazil illustrates to a certain extent the academic debate around evidence-based policy (Cairney, 2016; Easterly, 2016; Newman, 2017). Supporters of incorporating science into politics, despite its challenges (Newman et al., 2017), tend to argue that it is evidence (Costa et al., 2019), and not emotion, intuition, ideology or isolated anecdotes, that should feed policymaking (Goering \& Piat, 2016). If an argument cannot be statistically supported and explained, it carries less weight for policy making (Liebman, 2013). Critics of this scientific method argue that the term 'evidence' itself is rather subjective since it fails to encompass the complexity of social phenomena (Cowen et al., 2017; Mullen, 2016; Rodriguez et al.; 2017; Saltelli \& Giampietro, 2015; Sinclair et al., 2019). In addition, skeptics argue that it is not uncommon for scientists to disagree even after enjoying plenty of time to collect and analyse large sets of data (Saltelli \& Giampietro 2017).

In the context of crisis management, this long-standing academic debate tends to become even more heated. In the context of the US, which has now the largest number of infections to the novel coronavirus and deaths to COVID-19 worldwide, the president and its main scientific advisor cannot agree over which direction the country is heading to (Haffajee \& Mello, 2020; Washington Post, 2020). This is because time is of the 
essence. Crises are extraordinary situations that demand immediate response with minimum, incomplete or no information whatsoever (Moynihan, 2008). In these moments, decision makers are elevated to a position that society looks up for coherent explanations and coordinated actions to reduce their anxiety over the effects of the unfolding event in their routines (Boin et al., 2016; Lazzarini \& Musacchio, 2020).

It is not only limited time that decision makers are constrained by. They are also unable to process every piece of critical information that is given to them on a daily, or even hourly, basis (James \& Wooten, 2010). This makes them resort to cognitive mechanisms that help them effortlessly organize and prioritize thoughts and interests (Kahneman, 2003). Values and beliefs shaped by decision makers' experiences are the variables that set in motion where and how each piece of information stacks up (Abers et al. 2013; Clandinin \& Caine, 2013; Codato et al., 2015; Gauchat, 2015; Walsh, 2018). Humans, in general, seek comfort in messages that confirm our idiosyncrasies (Cook \& Smallman, 2008). We try our best to avoid the psychological stress that conflicting information has on challenging our prior set of beliefs forcing us to review and shift preconceived courses of action (Brehm \& Cohen, 1962). Public authorities tend to cognitively react to avoid penalizing their beliefs just as most people do (Carnielli, 2008).

Nevertheless, national leaders live under the public eye. They are not allowed to err as frequently as normal people do (Flyvbjerg et al.,2002). They must find ways to enhance 
their decision-making processes (Willems \& Van Dooren, 2016). Consulting with experts from different fields about a particular issue during critical times can certainly help them in this endeavor (Alexiadou \& Gunaydin, 2019). They could also momentarily gather a limited number of advisors that are thoughtful in their proposals and able to communicate effectively (Davidson, 2017; Walsh, 2018) to provide them with daily updates and recommendations. This deliberative process, however, can quickly become time consuming and unproductive (Scolobig et al., 2016). Thus a structure guiding advisors to share opinions and help the decision maker easily grasp a myriad of viewpoints is highly desirable.

Reflective reports help advisors incorporate elements of critical thinking into their communication with the decision maker. Leaders often look for resourceful analysis (Koh, 2017). In the deliberative process proposed in this study, advisors are not expected to debate with other advisors (Martin, 2000). They are, instead, expected to outline their opinion in the most concise and simplest form. While actively listening to each advisor, leaders should pay less attention to the argument itself than to assumptions, examples and generalizations advisors put forth. For instance, if a comparative example is brought up to substantiate an argument, leaders should ask themselves whether such comparison is valid in the first place. Also, anecdotal evidence can indeed be a sign of an emerging problem or solution (Parnell, 2017). However, it is the rationality, especially scientific, supporting the significance of an 
outlier and the trade-offs that it ensues that must be carefully considered by the decision maker (Rosenthal \& Kouzmin, 1997).

This paper, therefore, proposes that national leaders encourage advisors to expose the assumptions and limitations of their recommendations. National leaders also need to ask advisors to structure reflective reports in the format of brief narratives (Sanne, 2008) that help them easily grasp the complexity of an argument. The objective of institutionalizing reflective reports into decision making under uncertainty is to ensure that leaders are not overwhelmed by the increasing number of information they are constantly bombarded with. The simple structure of reflective reports also helps leaders understand and remember the key points presented to them before making a decision (Wright \& Goodwin, 2009).

\section{Method}

The objective of reflective reports is to help decision makers and their ad hoc committee to make the best possible decisions under significant time, information and resource constraints. The main assumptions of adopting such a methodology is that leaders i) have selected the most thoughtful communicators (Stewart et al., 2020) in the country to join this crisis response task force and that these advisors ii) do not hesitate to challenge their own assumptions and swiftly change course when conflicting information emerges. The expectation is that leaders adopting this method can optimize decision-making processes and reduce the risks of making decisions that will act against the public interest (Scicluna \& Auer 2019). 
Figure: Structure of 4-Step Reflective Report

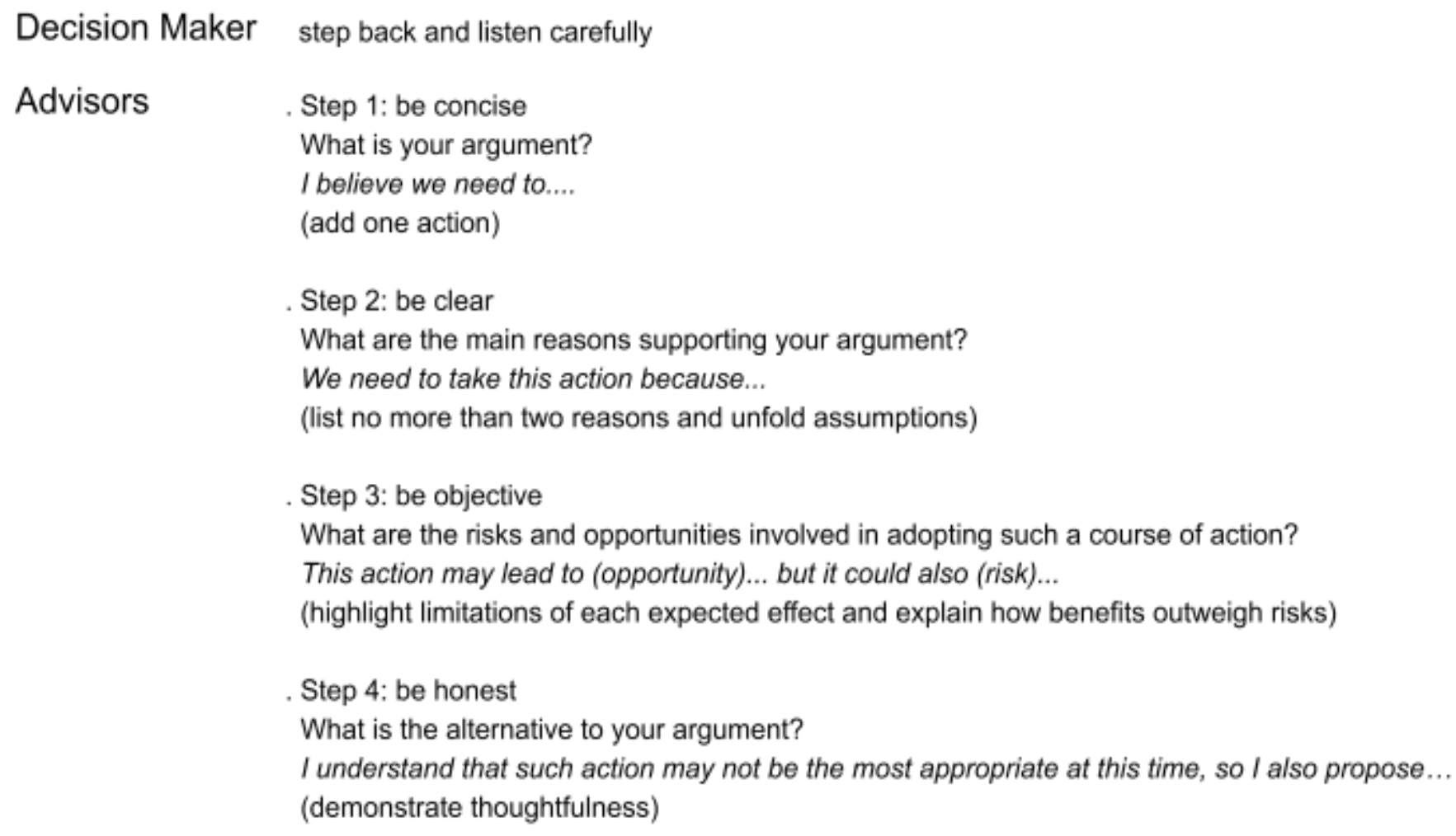

The length of each report varies in terms of the number of advisors and time constraints to reach a decision. The duration of the entire deliberative process should be kept to a minimum. Keeping it short ensures that the decision maker is not overwhelmed and can consider each argument before making a decision. Brevity in this deliberative process is also encouraged because it is expected that these meetings will occur daily and sometimes more than once a day.

\section{Limitations}


Reflective reports in the context of decision making under uncertainty present limitations. The first one has to do with the ability of advisors to translate complexity into compelling narratives without missing key facts. Advisors may also excessively simplify their interpretation of reality for the sake of clarity (Feitsma, 2018). The second limitation has to do with gatekeeping (Dargent, 2015, p. 112). National leaders must ensure that an ad hoc committee is not only composed of well-known experts in each field but it also gives opportunity for thoughtful communicators to share heterodox ways of thinking (Land et al., 2010; Ogbunu, 2020) and suggest unexpected courses of action

(Filgueiras, 2019, p. 9). The third limitation has to do with the cognitive ability of decision makers. Leaders need to be aware of their biases and blind spots (Edwards et al., 2016). Self-awareness allows decision makers to prioritize what it is in the interest of the public good rather than their own or their group. The last limitation assumes that each advisor's recommendation enjoys the same weight in the final decision. However, it is expected that leaders would be more inclined to consider recommendations that corroborate their preexisting values and beliefs (Buckley, 2017, p. 4) or be more acquiescent to advisors that had some leverage on their past decisions.

\section{Conclusion}

This article argues that national leaders can reduce the risks of the decisions they make under uncertain scenarios. This happens when leaders gather and actively listen to an ad hoc committee made up of thoughtful communicators (New Zealand Parliament, 2020). These advisors tap into compelling narratives to concisely and objectively share opinions (Clemson \& Samara, 2013). Leaders, however, face many constraints to 
respond to unfolding crises in a timely manner. These constraints lead them to invariably resort to mental shortcuts before reaching a decision. Selective attention and intuition, however, can lead to undesirable effects. Thus this paper proposes the addition of a straightforward reflective report into deliberative processes to help decision makers and advisors alike interpret and communicate perceived and shifting realities on the go.

Reflective report provides a simple structure for advisors to organize and challenge their own thoughts and opinions. It also helps national leaders grasp and process information. In the Brazilian context, it is expected that the president works closely with an array of experts from different fields and fairly listens to them before making decisions. This expectation, however, has become more of a wishful thinking recently. This is because there has been evidence that a recently organized ad hoc committee has not been given the necessary consideration by the president (Folha de São Paulo, 2020b). The national leader has also shown not being able to convince the society that his proposed policies are in the interest of the public good rather than his own political agenda (Raco \& Savini, 2019, p. 225).

\section{Acnowledgement}

No conflict of interest to report. No funding to declare.

\section{References}


ABC News. (2020, Mar 19). Trump touts chloroquine, old malaria drug that doctors say may help treat coronavirus. Youtube.

https://www.youtube.com/watch?v=3GuNbGC2D \&8

Abers, R., Abers, R. N., \& Keck, M. E. (2013). Practical authority: Agency and institutional change in Brazilian water politics. Oxford University Press.

Aguilera, J. (2020, Jan 30). 'There Are Sensible Voices That Are Emerging,' How Scientists Are Using Social Media to Counter Coronavirus Misinformation. Time. https://time.com/5773801/scientists-counter-misinformation-coronavirus/

Albertus, M. (2020, April 6). The Coronavirus Will Cause New Crises in Latin America. Foreign Policy.

https://foreignpolicy.com/2020/04/06/the-coronavirus-will-cause-new-crises-in-latin-amer ical

Alexiadou, D., \& Gunaydin, H. (2019). Commitment or expertise? Technocratic appointments as political responses to economic crises. European Journal of Political Research, 58(3), 845-865.

Ansell, C., \& Geyer, R. (2017). 'Pragmatic complexity'a new foundation for moving beyond 'evidence-based policy making'?. Policy Studies, 38(2), 149-167.

Barifouse, R. (2020, Apr 3). Coronavírus: por que o Brasil ainda não conseguiu fazer testes em massa?. BBC. https://www.bbc.com/portuguese/brasil-52145795

Benites, A. (2020, Apr 5). Mandetta, o conservador que vestiu o colete do SUS e entrincheirou Bolsonaro. El Pais.

https://brasil.elpais.com/brasil/2020-04-04/mandetta-o-conservador-que-vestiu-o-coletedo-sus-e-entrincheirou-bolsonaro.html

Bisht, A. (2020, Mar 27). Chaos and hunger amid India coronavirus lockdown. https://www.aljazeera.com/news/2020/03/chaos-hunger-india-coronavirus-lockdown-20 0327094522268.html

Boin, A., Stern, E., \& Sundelius, B. (2016). The politics of crisis management: Public leadership under pressure. Cambridge University Press.

Brehm, J. W., \& Cohen, A. R. (1962). Explorations in cognitive dissonance. 
Buckley, E. E. (2017). Technocrats and the Politics of Drought and Development in Twentieth-century Brazil. UNC Press Books.

Cabannes, Y., \& Lipietz, B. (2018). Revisiting the democratic promise of participatory budgeting in light of competing political, good governance and technocratic logics. Environment and Urbanization, 30(1), 67-84.

Cairney, P. (2016). The politics of evidence-based policy making. Springer.

Carnielli, W. (2008). The tyranny of knowledge. Manuscrito, 31(1), 511-518.

Clandinin, D. J., \& Caine, V. (2013). Narrative inquiry. In Reviewing qualitative research in the social sciences (pp. 178-191). Routledge.

Clemson, D., \& Samara, K. (2013, April). Crisis management simulations: Narrative inquiry into transformative learning. In European Conference on Research Methodology for Business and Management Studies (pp. 100-107). Kidmore End, England: Academic Conferences International.

Codato, A., Bolognesi, B., \& Roeder, K. M. (2015). A nova direita brasileira: uma análise da dinâmica partidária e eleitoral do campo conservador. Direita, volver, 121.

Cook, M. B., \& Smallman, H. S. (2008). Human factors of the confirmation bias in intelligence analysis: Decision support from graphical evidence landscapes. Human Factors, 50(5), 745-754.

Costa, G. (2020, Mar 21). População pobre terá dificuldades em isolamento, afirma infectologista. Agência Brasil.

https://agenciabrasil.ebc.com.br/direitos-humanos/noticia/2020-03/populacao-pobre-ter a-dificuldades-em-isolamento-afirma

Costa, V. G., Reis, G. R., Rodrigues, W., de Melo, M. P., dos Santos, G. J. V. G., Rodrigues, E. S. R., ... \& Silveira, J. M. (2019). Scientific evidence and technocracy as a public policy for the increase in the availability of ICU beds in Brazil: A systematic review. International Journal of Advanced Engineering Research and Science, 6(12).

Cowen, N., Virk, B., Mascarenhas-Keyes, S., \& Cartwright, N. (2017). Randomized controlled trials: How can we know "what works"?. Critical Review, 29(3), 265-292. 
Dargent, E. (2015). Technocracy and democracy in Latin America. Cambridge University Press.

Davidson, B. (2017). Storytelling and evidence-based policy: lessons from the grey literature. Palgrave Communications, 3(1), 1-10.

Dunn, C. G., Kenney, E., Fleischhacker, S. E., \& Bleich, S. N. (2020). Feeding Low-Income Children during the Covid-19 Pandemic. New England Journal of Medicine.

Easterly, W. (2016, Dec 23). Democracy Is Dying as Technocrats Watch. Foreign Policy. https://foreignpolicy.com/2016/12/23/democracy-is-dying-as-technocrats-watch/

Edwards, R., Gillies, V., \& Horsley, N. (2016). Early intervention and evidence-based policy and practice: Framing and taming. Social Policy and Society, 15(1), 1-10.

Estadão (2020). Saúde Pública versus Economia: a falsa dicotomia do atual debate. Estadão.

https://politica.estadao.com.br/blogs/blog-do-mlg/saude-publica-versus-economia-a-fals a-dicotomia-do-atual-debate/

Falcão, M. \& Vivas, F. (2020, Apr 6). Se governo tomar decisão que contrarie OMS, Supremo não deve validar, diz ministro. Globo.

https://g1.globo.com/politica/noticia/2020/04/06/se-governo-tomar-decisao-que-contrari e-oms-supremo-nao-deve-validar-diz-ministro.ghtml

Fauci, A. (2020, Apr 8). Coronavirus Q\&A With Anthony Fauci, MD. Jama. https://edhub.ama-assn.org/jn-learning/video-player/18433523

Feitsma, J. (2018). 'Rationalized incrementalism'. How behavior experts in government negotiate institutional logics. Critical Policy Studies, 1-18.

Feldwisch-Drentrup, H. (2020, Apr 2). How WHO Became China's Coronavirus Accomplice. Foreign Policy.

https://foreignpolicy.com/2020/04/02/china-coronavirus-who-health-soft-power/

Filgueiras, F. (2019). Governance, Brazil. Global Encyclopedia of Public Administration, Public Policy, and Governance. Springer, Cham. 
Flyvbjerg, B., Holm, M. S., \& Buhl, S. (2002). Underestimating costs in public works projects: Error or lie?. Journal of the American planning association, 68(3), 279-295.

Folha de São Paulo (2020, Feb 28). 'Se repetir cenário da China, coronavírus é administrável no Brasil', diz ministro da Saúde. Folha de São Paulo. https://www1.folha.uol.com.br/equilibrioesaude/2020/02/se-repetir-cenario-da-china-cor onavirus-e-administravel-no-brasil-diz-ministro-da-saude.shtml

Folha de São Paulo (2020a, Apr 8). Médica entusiasta da cloroquina contra Covid-19 já defendeu outras terapias sem evidências. Folha de São Paulo.

https://www1.folha.uol.com.br/equilibrioesaude/2020/04/medica-entusiasta-da-cloroquin a-contra-covid-19-ja-defendeu-outras-terapias-sem-evidencias.shtml

Folha de São Paulo (2020b). Bolsonaro desautoriza ministros, centraliza decisões sobre pandemia e esvazia comitê de crise. Folha de São Paulo.

https://www1.folha.uol.com.br/poder/2020/03/bolsonaro-desautoriza-ministros-centraliza -decisoes-sobre-pandemia-e-esvazia-comite-de-crise.shtml

Gauchat, G. (2015). The political context of science in the United States: Public acceptance of evidence-based policy and science funding. Social Forces, 94(2), 723-746.

Ghebreyesus, T. A. (2020, April 2). WHO Director-General's opening remarks at the Mission briefing on COVID-19 - 2 April 2020. World Health Organization.

https://www.who.int/dg/speeches/detail/who-director-general-s-opening-remarks-at-themission-briefing-on-covid-19---2-april-2020

Globo (2020, Apr 10). Unicamp diz que apoio ao uso da cloroquina contra coronavírus se baseia em 'evidências frágeis'. Globo.

https://g1.globo.com/sp/campinas-regiao/noticia/2020/04/10/coronavirus-unicamp-emite -nota-sobre-hidroxicloroquina-e-diz-que-apoio-ao-uso-em-tratamento-se-baseia-em-evi dencias-frageis.ghtml

Godin, M. (2020, Apr 9). Sweden's Relaxed Approach to the Coronavirus Could Already Be Backfiring. Time. https://time.com/5817412/sweden-coronavirus/

Goering, E. M. G. N. P., \& Piat, M. (2016). The At Home/Chez Soi Project: Moving Evidence into Policy. 
Governo do Brasil (2020, Mar 25). Ministério da Saúde autoriza uso de cloroquina para casos graves de coronavírus. Governo do Brasil.

https://www.gov.br/pt-br/noticias/saude-e-vigilancia-sanitaria/2020/03/ministerio-da-sau de-autoriza-uso-de-cloroquina-para-casos-graves-de-coronavirus

Haffajee, R. L., \& Mello, M. M. (2020). Thinking Globally, Acting Locally-The US Response to Covid-19. New England Journal of Medicine.

Head, B. W. (2008). Wicked problems in public policy. Public policy, 3(2), 101.

https://exame.abril.com.br/economia/bolsonaro-diz-que-com-coronavirus-brasil-dificilme nte-vai-crescer-2/

https://g1.globo.com/politica/noticia/2020/03/24/bolsonaro-pede-na-tv-volta-a-normalida de-e-fim-do-confinamento-em-massa.ghtml

James, E. H., \& Wooten, L. P. (2010). Leading under pressure: From surviving to thriving before, during, and after a crisis. Routledge/Taylor \& Francis Group.

Jansen, R. (2020, Mar 23). Brasil acerta nas medidas no combate ao coronavírus, mas desigualdade preocupa, dizem especialistas. Estadão.

https://saude.estadao.com.br/noticias/geral,brasil-acerta-nas-medidas-no-combate-ao-c oronavirus-mas-desigualdade-preocupa-dizem-especialistas, 70003244085

Jiang, S. (2020, Mar 16). Don't rush to deploy COVID-19 vaccines and drugs without sufficient safety guarantees. https://www.nature.com/articles/d41586-020-00751-9

Jornal Nacional (2020, Apr 8). Em pronunciamento, Bolsonaro defende uso da cloroquina para tratamento do coronavírus. Globo.

https://g1.globo.com/jornal-nacional/noticia/2020/04/08/em-pronunciamento-bolsonarodefende-uso-da-cloroquina-para-tratamento-do-coronavirus.ghtml

Jornal Nacional (2020a, Mar 24). Bolsonaro pede na TV 'volta à normalidade' e fim do 'confinamento em massa' e diz que meios de comunicação espalharam 'pavor'. Globo. https://g1.globo.com/politica/noticia/2020/03/24/bolsonaro-pede-na-tv-volta-a-normalida de-e-fim-do-confinamento-em-massa.ghtml

Kahneman, D. (2003). Maps of bounded rationality: Psychology for behavioral economics. American economic review, 93(5), 1449-1475. 
Khalik, S. (2020, Feb 4). 4 local coronavirus transmissions but no community spread yet as source of infection is known: Gan Kim Yong. Strait Times.

https://www.straitstimes.com/singapore/health/four-local-transmissions-but-no-communi ty-spread-yet-as-source-of-infection-is

Koh, G. (2017). Bureaucratic rationality in an evolving developmental state: Challenges to governance in Singapore. In Singapore (pp. 85-112). Routledge.

Land, R., Meyer, J. H., \& Baillie, C. (2010). Editors' preface: threshold concepts and transformational learning (Vol. 42, pp. ix-xlii). Sense; Brill.

Lazzarini, S. G., \& Musacchio, A. (2020). Leviathan as a Partial Cure? Opportunities and Pitfalls of Using the State-Owned Apparatus to Respond to the Covid-19 Crisis. Opportunities and Pitfalls of Using the State-Owned Apparatus to Respond to the COVID-19 Crisis (March 27, 2020).

Liebman, J. B. (2013). Building on recent advances in evidence-based policymaking. The Hamilton Project. Brooking Institutions.

Lima, C. (2020). Fiocruz lança Plano de Contingência para Covid-19.

Lunn, P. D., Belton, C. A., Lavin, C., McGowan, F. P., Timmons, S., \& Robertson, D. A. (2020). Using Behavioral Science to help fight the Coronavirus. Journal of Behavioral Public Administration, 3(1).

Martin, B. (2000). Behind the scenes of scientific debating. Social Epistemology, 14(2-3), 201-209.

Moynihan, D. P. (2008). Learning under uncertainty: Networks in crisis management. Public Administration Review, 68(2), 350-365.

Mulier, T. (2020, Mar 29). WHO Says It's Working With Taiwan Experts After Video Goes Viral.

https://www.bloomberg.com/news/articles/2020-03-29/who-says-it-s-working-with-taiwa n-experts-after-video-goes-viral

Mullen, E. J. (2016). Reconsidering the 'idea' of evidence in evidence-based policy and practice. European journal of social work, 19(3-4), 310-335. 
Newman, J., Cherney, A., \& Head, B. W. (2017). Policy capacity and evidence-based policy in the public service. Public Management Review, 19(2), 157-174.

Newman, J. (2017). Deconstructing the debate over evidence-based policy. Critical Policy Studies, 11(2), 211-226.

New Zealand Parliament (2020). COVID-19: What is the Epidemic Response Committee?. New Zealand Parliament. https://www.parliament.nz/en/get-involved/features/covid-19-what-is-the-epidemic-respo nse-committee/

Ogbunu, C. B. (2020, Apr 5). Don't Be Fooled by Covid-19 Carpetbaggers. Wired. https://www.wired.com/story/opinion-dont-be-fooled-by-covid-19-carpetbaggers/

Palmer, J. (2019, Jul 4). China's Overrated Technocrats. Foreign Policy. https://foreignpolicy.com/2019/07/04/chinas-overrated-technocrats-stem-engineering-xi-j inping/

Parnell, J. A. (2017). The contribution of behavioral economics to crisis management decision-making. Journal of Management \& Organization, 1-16.

Piller, C. (2020, Mar 26). 'This is insane!' Many scientists lament Trump's embrace of risky malaria drugs for coronavirus. Science.

https://www.sciencemag.org/news/2020/03/insane-many-scientists-lament-trump-s-emb race-risky-malaria-drugs-coronavirus

Pinheiro-Machado, R. (2020, Mar 31). Coronavírus: Bolsonaro só acredita na 'ciência' quando o resultado Ihe interessa. Thelntercept Brasil.

https://theintercept.com/2020/03/31/coronavirus-bolsonaro-anti-ciencia/

Pinto, A. C., Cotta, M., \& de Almeida, P. T. (2018). Beyond Party Government? Technocratic Trends in Society and in the Executive. In Technocratic Ministers and Political Leadership in European Democracies (pp. 1-27). Palgrave Macmillan, Cham.

Raco, M., \& Savini, F. (Eds.). (2019). Planning and knowledge: How new forms of technocracy are shaping contemporary cities. Policy Press.

Reeves, P. (2020, Mar 19). In Brazil, Government Has Been Slow To Respond To Coronavirus Threat. NPR. 
Resende, S. \& Matoso, F. (2020, Mar 25). Mourão diz que posição do governo 'é uma só': isolamento e distanciamento social. Globo.

https://g1.globo.com/politica/noticia/2020/03/25/mourao-diz-que-posicao-do-governo-euma-so-isolamento-e-distanciamento-social.ghtml

Reuters (2020, Mar 16). Bolsonaro diz que, com coronavírus, Brasil dificilmente vai crescer $2 \%$. Exame.

Rodriguez, L., George, J. R., \& McDonald, B. (2017). An inconvenient truth: why evidence-based policies on obesity are failing Māori, Pasifika and the Anglo working class. Kōtuitui: New Zealand Journal of Social Sciences Online, 12(2), 192-204.

Rosenthal, U., \& Kouzmin, A. (1997). Crises and crisis management: Toward comprehensive government decision making. Journal of Public Administration Research and Theory, 7(2), 277-304.

Saltelli, A., \& Giampietro, M. (2015). The fallacy of evidence based policy. arXiv preprint arXiv:1607.07398.

Saltelli, A., \& Giampietro, M. (2017). What is wrong with evidence based policy, and how can it be improved?. Futures, 91, 62-71.

Sanne, J. M. (2008). Incident reporting or storytelling? Competing schemes in a safety-critical and hazardous work setting. Safety Science, 46(8), 1205-1222.

Scicluna, N., \& Auer, S. (2019). From the Rule of Law to the Rule of Rules:

Technocracy and the Crisis of EU Governance. West European Politics, 42(7), 1420-1442.

Scolobig, A., Pellizzoni, L., \& Bianchizza, C. (2016). Public Participation and Trade-Offs in Flood Risk Mitigation: Evidence from Two Case Studies in the Alps. Nature and Culture, 11(1), 93-118.

Sen, B. A. (2010). Reflective writing: a management skill. Library management.

Sinclair, S., McHugh, N., \& Roy, M. J. (2019). Social innovation, financialisation and commodification: A critique of social impact bonds. Journal of Economic Policy Reform, $1-17$. 
Stewart, E., Ercia, A., Greer, S. L., \& Donnelly, P. D. (2020). Between a rock and a hard place: Comparing arms' length bodies for public involvement in healthcare across the UK. Health Policy.

UOL (2020, Apr 8). "Desemprego leva à morte" e mais: as frases do pronunciamento de Bolsonaro. UOL.

https://noticias.uol.com.br/politica/ultimas-noticias/2020/04/08/frases-pronunciamento-b olsonaro.htm

Vespa, T. (2020, Mar 22). "Se não morrer desse vírus, morro de fome", diz ambulante de 65 anos. UOL.

https://noticias.uol.com.br/cotidiano/ultimas-noticias/2020/03/22/se-nao-morrer-desse-vi rus-morro-de-fome-diz-ambulante-de-65-anos.htm

Walsh, M. M. (2018). Science communication in risk management at a high-incidence location for suicide (Doctoral dissertation, University of Otago).

Washington Post. (2020, April 6). Trump bristled when asked about promoting hydroxychloroquine. Then he cut Fauci off. Youtube.

https://www.youtube.com/watch?v=QEtZGZdUGwA

Willems, T., \& Van Dooren, W. (2016). (De) politicization dynamics in public-private partnerships (PPPs): Lessons from a comparison between UK and Flemish PPP policy. Public Management Review, 18(2), 199-220.

Wood, J. (2020, Mar 17). The World Health Organization has called on countries to 'test, test, test' for coronavirus - this is why. World Economic Forum. https://www.weforum.org/agenda/2020/03/coronavirus-covid-19-testing-disease/

Wright, G., \& Goodwin, P. (2009). Decision making and planning under low levels of predictability: Enhancing the scenario method. International Journal of Forecasting, 25(4), 813-825.

Zeitlin, J. (Ed.). (2015). Extending experimentalist governance?: the European Union and transnational regulation. OUP Oxford. 